\title{
NÄKÖKULMIA KOULUN JA TYÖPAIKAN KIUSAAMISSUHTEISIIN
}

\section{Sini Rainivaara, FM}

Viestintätieteiden laitos, Jvuäskylän yliopisto

Sanna Karhunen, FM

Viestintätieteiden laitos, Jyuäskylän yliopisto

\section{TIIVISTELMÄ}

Tässä artikkelissa tarkastellaan koulu- ja työpaikkakiusaamista vuorovaikutussuhteiden näkökulmasta. Kiusaaminen määritellään pitkäkestoiseksi prosessiksi, jossa yksilö kokee joutuvansa toisen yksilön, ryhmän tai yhteisön järjestelmällisen ja toistuvan loukkaavan ja/tai aggressiivisen käyttäytymisen kohteeksi. Koulu- ja työpaiklkakiusaamisen ilmiöissä on havaittu paljon yhteneväisyyksiä, mutta myös eroja. Kiusaamisilmiötä on tähän mennessä tutkittu pääasiallisesti yksilön, ryhmän ja yhteisön näkökulmista. Tuore näkökulma sen sijaan on kiusaamisen tarkastelu vuorovaikutussuhteiden tasolla. Artikkelissa käsitellään kiusaamisilmiötä nimenomaan vuorovaikutussuhteen - kiusaamissuhteen - näkökulmasta. Kiusaamissuhteella tarkoitetaan tässä artikkelissa ei- toivottua vuorovaikutussuhdetta, jossa esiintyy viestintää, jonka vähintään yksi osapuoli kokee kiusaamisena ja joka voi uhata hänen henkistä ja fyysistä hyvinvointiaan. Artikkelissa tarkastellaan kiusaamissuhteen osapuolia sekä kiusaamissuhteessa esiintyvää loukkaavaa ja uhkaavaa viestintää. Lisäksi pohditaan, millainen vuorovaikutussuhde kiusaamissuhde on, miten se saa allkunsa ja miten sitä ylläpidetään. Artikkelissa myös pohditaan kiusaamissuhteessa ilmenevään viestintään liittyviä tulkintaeroja. Kiusaamissuhdetta tarkastellaan koulun sekä työpaikan konteksteissa. Asiasanat: kiusaaminen, kiusaamissubde, koulukiusaaminen, työpaikkakiusaaminen, viestintäkäyttäytyminen, worovaikutussubde 


\section{JOHDANTO}

Vuorovaikutussuhteissa saamamme onnistumisen elämykset ovat suoraan yhteydessä hyvinvointiimme ja onnellisuuteemme. Vastavuoroisesti vuorovaikutussuhteiden puute ja niiden karikot edustavat kokemusmaailmamme varjopuolta. Koulun ja työpaikan vuorovaikutussuhteet ovat merkittävä osa elämäämme, vietämmehän eri ikäkausina valtaosan ajastamme niiden parissa.

Tässä artikkelissa tarkastelemme sellaisia koulun ja työpaikan vuorovaikutussuhteita, joita värittää kokemus kiusaamisesta. Kiusaamisella tarkoitetaan pitkäaikaista prosessia, jossa yksilöön kohdistuu toisen yksilön, ryhmän ja/tai yhteisön toimesta järjestelmällistä ja ei-toivottua käytöstä, joka voi olla aggressivista ja/tai eri tavoin loukkaavaa (Einarsen 2000, 381; Leymann 1996, 168; Olweus 1992, 14-15; 2003, 63; Salmivalli 1998, 30-31; 2003, 11).

Vuorovaikutussuhde on puheviestinnän peruskäsite, jonka tutkimuksella ja sovelluksilla on tieteenalallamme pitkät perinteet. Muilla tieteenaloilla, kuten psykologiassa ja kasvatustieteissä, kiusaamista on tutkittu systemaattisesti niin koulun kuin työpaikan kontekstissa. Tässä artikkelissa tarkastelemme kiusaamista vähemmän tutkitusta näkökulmasta, jossa vuorovaikutussuhde ja kiusaaminen yhdistyvät kiusaamissuhteen käsitteeksi. Kiusaamissubteella tarkoitamme ei-toivottua vuorovaikutussubdetta, jossa esizntyy toistwasti viestintää, jonka ainakin subteen y ksi osapuoli kokee kinsaamisena ja joka on jatkuessaan merkittäuä ubka väbintään ybden osapuolen psyykekiselle ja foysiselle byninvoinnille.

Kiusaaminen toteutuu viestinnän keinoin ja se vaikuttaa kiusaamissuhteen osapuolten jokapäiväiseen elämään tavalla tai toisella. Tässä artikkelissa pohdimme joitakin vuorovaikutussuhteisiin liittyviä näkökulmia, joista kiusaamisilmiötä voidaan tarkastella. Lisäksi pohdimme, millainen vuorovaikutussuhde kiusaamissuhde on luonteeltaan sekä millaisia yhteneväisyyksiä ja eroavaisuuksia kiusaamissuhteilla koulussa 
ja työpaikalla on. Aluksi tarkastelemme lyhyesti, miten kiusaaminen koulussa ja työssä on määritelty ja millaisista näkökulmista sitä on tutkittu.

\section{KIUSAAMINEN KOULUSSA JA TYÖPAIKALLA}

Pörhölä, Karhunen ja Rainivaara (2006, 251-252) ovat vertailleet kiusaamisesta käytettyjä käsitteitä, ja heidän mukaansa bullying (kiusaaminen) ja victimization (uhriutuminen) ovat varsin vakiintuneita käsitteitä lasten ja nuorten parissa tapahtuvasta häirinnästä puhuttaessa. Työpaikkakiusaamisen käsitteellä on sen sijaan monia synonyymeja, kuten esimerkiksi harassment (häirintä), mobbing (mobbaus) ja psycbological terror sekä emotional abuse (henkinen väkivalta). Tässä artikkelissa käytämme käsitettä kiusaaminen silloin, kun tarkastelemme ilmiötä molemmissa tarkastelemissamme konteksteissa, ja käsitteitä koulukiusaaminen ja työpaikkakiusaaminen kuvatessamme ilmiötä tietyssä kontekstissa.

Työpaikkakiusaamisen synonyymeinä voidaan käyttää termejä "häirintä" tai "epäasiallinen kohtelu", jotka ovat käytössä esimerkiksi vuonna 2003 voimaan astuneessa työturvallisuuslaissa (Työturvallisuuslaki 23.8.2002/738, 28 §). On kuitenkin huomioitava, että vaikka puhumme myös tässä artikkelissa kiusaamisesta ilmiönä kahdessa eri kontekstissa, ovat ne monilta osin hyvin erilaisia. Luettavuuden vuoksi olemme kuitenkin pitäytyneet em. termeissä, mutta pyrimme tuomaan esille ilmiöiden eroavaisuuksia.

Koulun arki on täynnä konfliktitilanteita, joissa kaksi tai useampi tasavahva oppilas nahistelee keskenään. Kaikki lasten ja nuorten keskinäinen nahistelu ei kuitenkaan ole kiusaamista. Rigby $(2004,288)$ korostaa määritelmässään, että koulukiusaaminen eroaa olennaisesti tällaisesta konfliktista, sillä kiusaamisessa on kyse vallan epätasaisesta jakautumisesta siten, että toisen dominoidessa toinen joutuu alistumaan. Myös Naylor ja Cowie $(1999,467)$ näkevät kiusaamisen systemaattisena vallan väärinkäyttönä. Koulukiusaaminen määritelläänkin usein nimenomaan 
pitkäkestoiseksi prosessiksi, jossa yksi oppilas joutuu toistmasti toisten oppilaiden kielteisen käyttäytymisen kohteeksi (Olweus 1992; 2003; Pikas 1990; Salmivalli 2003). Olweus (1992, 14-15; 2003, 63) tiivistää kolme koulukiusaamiselle ominaista piirrettä, jotka ovat 1) aggressiivinen käyttäytyminen tai tahallinen satuttaminen, 2) kielteisten tekojen toistuvuus ja pitkäkestoisuus sekä 3) vallan epätasapainoinen jakautuminen.

Myös työelämässä esiintyy moninaisia kielteisiä ilmiöitä, vaikka työyhteisöjen vuorovaikutuksen tutkimus onkin tähän asti keskittynyt lähinnä positiivisten ilmiöiden, kuten sitoutumisen, tarkasteluun. Vardi ja Weitz (2004, xv-xviii) toteavat, että on pelkästään realistista huomioida tutkimuksissa myös työelämän kielteiset puolet. Duck (1994) on myös todennut, että voidaksemme ymmärtää vuorovaikutussuhteita, on niihin liittyvät niin myönteiset kuin kielteisetkin elementit otettava huomioon yhtä lailla.

Työpaikkakiusaamiselle on käytetyimpien määritelmien mukaan leimallista ei-toivottujen, negatiivisten tekojen ja sanojen toistuvuus, prosessin pitkäaikaisuus sekä kiusatuksi itsensä kokevan tunne sïtä, että hän on kyvytön puolustautumaan ja vaikuttamaan tilanteeseen (Einarsen 2000, 381; Leymann 1996, 168; Rayner \& Cooper 2006, 124; Vartia 2003, 11). Määritelmiin nojaten yksittäinen riitatilanne työtovereiden välillä ei siten täytä työpaikkakiusaamiseksi nimeämisen edellytyksiä, vaikka sïnä esiintyvä viestintä olisi miten loukkaavaa tahansa.

Koulu- ja työpaikkakiusaamisen tutkimus käynnistyi erilaisten yksilötekijöiden tutkimuksella, mutta näkökulmaa on myöhemmin laajennettu useamman tason tekijöiden sekä niiden yhteisvaikutusten tarkasteluun (esim. Einarsen ym. 2003a; Salmivalli 2003). Pörhölä, Karhunen ja Rainivaara (2006, 273-286) jäsentävät kiusaamisen tämänhetkistä tutkimuskenttää koulussa ja työpaikalla yksilön, ryhmän ja organisaation näkökulmiin.

Koulukiusaamista tarkastelevassa kirjallisuudessa ja empiirisissä tut- 
kimuksissa kiusaamista selittäviä tekijöitä on siis etsitty laajalti esimerkiksi erilaisista yksilötason (riski)tekijöistä, kuten esimerkiksi lasten ja nuorten fyysisestä olemuksesta, arkuudesta, itsetunnosta, aggressiosta (proaktiivinen ja reaktiivinen), sosiaalisesta älykkyydestä, itsekorostuksen tarpeesta selä perhetaustasta (esim. Kaukiainen 2003; Olweus 1992; Salmivalli 1998; 2003; 2005). Nämä pääasiassa kiusaajiin ja kiusattuihin liittyvät yksilötason tekijät voivat tosin yhtä hyvin olla kiusaamisen seurausta, eikä niiden yksiselitteisesti voida ajatella olevan ainoastaan syitä kiusaamiselle. Selityksiä koulukiusaamisen syntymiselle ja jatkumiselle on haettu yksilötekijöiden lisäksi moninaisista ryhmätason tekijöistä, kuten rooleista, normeista, statuksesta ryhmässä sekä kiusaamisen oikeuttamiseen liittyvistä diskursseista (esim. Salmivalli 1998; 1999; Salmivalli \& Voeten 2004; Teräsahjo \& Salmivalli 2002).

Koulukiusaamisen yhteydessä on yhteisötason tekijöitä tutkittu vähemmän kuin yksilötason tekijöitä. Payne ja Gottfredson (2004, 159-164) sekä Salmivalli $(2003,38-39)$ toteavat, että organisaatiotason näkökulmasta selityksiä koulukiusaamiselle on haettu muun muassa koulun toimintakulttuurista, ilmapiiristä, koulun fyysisestä olemuksesta (sijainti, oppilasmäärä, luokkakoko, viihtyvyys) sekä niin oppilaiden kuin opettajien valmiudesta puuttua kiusaamiseen. Koulukiusaamista ja sen syitä tarkastelevassa tutkimuksessa on melko harvoin otettu samanaikaisesti huomioon niin yksilö- kuin yhteisötason tekijöitä. Ma: n (2002) laajaan kanadalaiseen aineistoon pohjautuva tutkimus tarjoaa kuitenkin näkökulmia molempiin. Ma:n tutkimustulokset antavat viitteitä siitä, että yksilötekijät voivat olla koulutason tekijöitä merkittävämpiä kiusaamisen selittäjï. Tulokset kuitenkin osoittavat, että myönteinen ilmapiiri, selkeä kurinpidollinen kulttuuri sekä yhteistyö koulun ja vanhempien välillä voivat toimia kiusaamista ehkäisevällä tavalla alemmilla luokilla. Ylemmillä luokilla korkeat oppimistavoitteet voivat ehkäistä kiusaamisen syntyä.

Zapfin ja Einatsenin (2003) koonnin mukaan yksilötekijöiden yh- 
teyttä työpaikkakiusaamiseen on kartoitettu muun muassa kiusatuksi identifioidun sosiaalisten taitojen, itseluottamuksen sekä aggressiivisuuden perusteella. Kiusatun luonteenpiirteiden avulla voidaan kuitenkin osoittaa vain hänelle tyypillisiä tapoja vastata kohtaamaansa kiusaamiseen. Syy-seuraussuhteita niiden perusteella ei voida tunnistaa.

Ryhmätason selityksistä tunnetuimpia on niin sanottu syntipukkiilmiö. Tällöin yhteen työyhteisön jäseneen projisoidaan työryhmässä ilmenevät, työympäristön ongelmallisuuden aiheuttamat aggressiot ja syytökset, jotta paine muun ryhmän sisällä helpottuisi. Syntipukin roolista muodostuukin ryhmän toimintakyvyn näkökulmasta varsin tarpeellinen. (Esim. Lahtinen ym. 2002, 100; Thylefors 1987, Vartian 2003, 17 mukaan.) Työpaikkakiusaamisen tutkimuksissa ilmiön syntyyn vaikuttavia organisaatiotason selityksiä on etsitty pääasiallisesti erilaisista työyhteisöön, työhön ja sen tekemiseen liittyvistä tekijöistä (tai niihin liittyvistä ongelmista), kuten työtehtävien jakautumisesta, johtamistavoista, uhrin sosiaalisen aseman merkityksestä työyhteisössä sekä työpaikan moraalisesta ilmapiiristä (Einarsen 2000, 390-392).

Leymannin (1996) mukaan yksilön persoonallisuudella on vähäinen merkitys työpaikkakiusaamisen uhriksi valikoitumisessa. Suurempi merkitys on työyhteisön olosuhteilla. Zapf (1999) puolestaan näkee, että kiusaamisessa on aina viime kädessä kyse henkilökohtaisesta käyttäytymisvalinnasta. Ongelmat liittyen esimerkiksi työolosuhteisiin, johtajuuteen tai organisaation muutoksiin eivät johda kiusaamiseen, vaikka riskitekijöinä ne voidaan toki nähdä. Kolmas näkökulma yhdistää edellä kuvatut ja näkee kiusaamisen niin yksilöön kuin ympäristöön liittyvien tekijöiden vuorovailsutuksen tuloksena (Randall 2001, 22). Toisin sanoen kiusaaminen on yksilöille mahdollista vain, jos ympäristö (tietoisesti tai tiedostamattaan) mahdollistaa ja sallii sen.

Salmivallin (2003, 38) mukaan koulukiusaamista ovat valtaosin tutkineet kehityspsykologit ja työpaikkakiusaamista työ- ja organisaatiopsykologit. Tämä selittääkin hänen mukaansa sitä, että työpaikoilla 
on kouluja enemmän tutkittu organisatorisen tason tekijöiden yhteyttä kiusaamiseen, kun koulukiusaamista taas on selitetty henkilökohtaisilla ominaisuuksilla. Kiusaamistutkimuksen mielenkiintoisena piirteenä on jatkuva keskustelu siitä, voidaanko syy kiusaamiseen löytää yksilöistä vai heitä ympäröivästä yhteisöstä.

Kiusaamistutkimuksessa toistaiseksi vähemmälle huomiolle on jäänyt se vuorovaikutussuhde, joka kiusaamistilanteen osapuolilla on. Kiusaamisen osapuolten viestintää on tutkittu toisistaan irrallisena mutta heidän vuorovaikutussuhdettaan ei toistaiseksi ole valotettu juurikaan. Kiusaamistutkimuksessa määritelmät ja käsittelytavat pitävät toki sisällään suhdenäkökulman. Esimerkiksi Olweuksen (1992, 14-15) näkemys koulukiusaamisesta pitkäkestoisena ja toistuvana toisen ihmisen tahallisena satuttamisena sisältää ajatuksen kiusaamisesta subteena. Olweus täsmentää määritelmäänsä siten, että kiusaạminen vaatii vallan epätasaista jakautumista nimenomaan kiusaajan/kiusaajien ja kiusatun välisessä suhteessa (asymmetrinen valtasuhde, asymmetrical ponver relationship). Myös Pepler ja Craig (2000, 5-6) ovat korostaneet, että koulukiusaamisessa on nimenomaan kyse lasten ja nuorten välisistä vuorovaikutussuhteista.

Myös työpaikkakiusaamista käsittelevissä tuoreimmissa artikkeleissa on todettu, että kiusaamista voidaan tarkastella jatkuvana vuorovaikutussuhteena toistuvien, toisistaan irrallaan olevien kiusaamistilanteiden sijaan (esim. Keashly \& Jagatic 2003; Pörhölä, Karhunen \& Rainivaara 2006). Einarsen (1996) näkee, että kiusaamisen kohde ei myöskään ole vain vastaanottavainen uhri vaan aktiivinen tulkitsija. Kiusaamissuhteen molemmat osapuolet ovat siten omalla tavallaan suhteensa kehitykseen vaikuttavia osapuolia.

Vallan epätasapaino liitetään usein myös työpaikkakiusaamisen määritelmään. Einarsen ym. (2003b, 10-11) kokoavat vallan käsitteeseen kuuluvaksi tiettyyn asemaan kuuluvan vallan (kuten esimies-alaissuhteessa) mutta myös työntekijän osaamisen mukanaan tuoman vallan. 
Esimerkiksi tiettyyn tehtävänkuvaan liittyvä tieto voi antaa työntekijälle mahdollisuuden käyttää - tai väärinkäyttää - valtaansa tiedon jakamista säätelemällä. Yhtä lailla valta tai sen epätasapaino liitetään vaikutusmahdollisuuksiin vuorovaikutustilanteessa. Kun konfliktissa molemmilla osapuolilla katsotaan olevan yhtäläiset mahdollisuudet omien näkemysten esilletuomiseen, on toinen osapuoli kiusaamistilanteessa toistuvasti altavastaajana.

Lähtökohtanamme tässä artikkelissa on, että vuorovaikutussuhteen tavoin kiusaamissubde kehittyy ja sitä ylläpidetään, kun suhteen osapuolet ovat vuorovaikutuksessa. Kiusaamisessa on kyse ongelmallisesta vuorovaikutussuhteesta, joka on ainakin toisen osapuolen näkökulmasta ei-toivottu ja jossa ainakin toinen osapuoli kokee toistuvasti tulevansa kiusatuksi. Kiusaamissuhteen olemassaolo on myös vakava uhka vähintään toisen osapuolen hyvinvoinnille. Pohdimme kiusaamissuhteen käsitettä tarkemmin seuraavassa luvussa.

\section{KIUSAAMINEN VUOROVAIKUTUSSUHTEENA}

Kiusaamissubteen kebittyminen

Aiemmissa kiusaamista tarkastelevissa tutkimuksissa on kartoitettu lähinnä joko kiusaajan toimintaa eli käytännössä erilaisia kiusaamisen muotoja tai sitä, miten kiusatut pyrkivät selviytymään yksittäisissä kiusaamistilanteissa tai koko prosessin aikana. Vähemmälle huomiolle on jäänyt se, miten osapuolet rakentavat ja ylläpitävät vuorovaikutussuhdettaan.

Kiusaamissuhde vaatii aikaa kehittyäkseen. Joissain tapauksissa jo ensikohtaaminen voi ennakoida vaikeuksia, ja suhteen kielteinen kehitys voi siten alkaa jo hyvin pian ensikohtaamisesta. Toisinaan osapuolten välillä voi olla toimiva vuorovaikutussuhde hyvinkin pitkään. Kiusaamissuhteiden alkamisesta ja niiden elinkaaresta tiedetään toistaiseksi vähän, eikä vuorovaikutussuhteen kehittymiselle kiusaamissuh- 
teeksi liene edes mahdollista osoittaa tiettyä alkamisajankohtaa.

Toisaalta voidaan myös ajatella, että moni vuorovaikutussuhde ei muodostu kiusaamissuhteeksi, vaikka edellytyksiä kielteiselle kehitykselle olisikin. Tutkijan näkökulmasta saavuttamattomia, mutta hedelmällisiä tutkimuskohteita olisivat ne vuorovaikutussuhteet, jotka melkein johtivat kiusaamiskokemuksiin.

Pikas (1990, 70-72) näkee koulukiusaamisen taustalla kolme erilaista ryhmämekanismia, jotka yhdessä voivat saada aikaan kiusaamista. Kiusaaminen voi saada alkunsa suhteellisen harmittomasta koululaisten tavasta testata toisiaan ja vertailla toistensa yksilöllisiä ominaisuuksia. Mikäli testauksen tuottamia havaintoja ei pidetä tuttuina ja turvallisina, testaamisen kohde saatetaan leimata erilaiseksi. Tapahtumat voivat johtaa kiusaamiseen, mikäli testauksen kohteeseen lisäksi liitetään erilaisia uhkakuvia. Kolmantena vaikuttavana ryhmätekijänä kiusaamisen synnyssä toimii Pikasin mukaan vahvistaminen, jolla hän tarkoittaa ryhmän sisällä tapahtuvaa jäsenten kielteisen käyttäytymisen vahvistamista. Vahvistaminen lisää ryhmän sisäistä yhtenäisyyttä ja yllyttää ryhmän jäseniä uhria vastaan.

Työpaikalla yhtenä mahdollisena kiusaamiseen johtavana tapahtumana nähdään esimerkiksi ratkaisematta jäänyt, alun perin työtehtävään liittyvä konflikti. Toisen selityksen mukaan kiusaaja on valinnut kohteekseen sopivalta tuntuvan työtoverin jokseenkin satunnaisesti. Tällöin kiusaaminen voidaan nähdä intentionaalisena ja välineellisenä, ts. keinona saavuttaa jokin tavoite (dispute-related bullying ja predatory bulbing, esim. Einarsen 1999).

Kiusaamissuhteen voidaan katsoa saaneen alkunsa, kun loukkaaviksi koetut tilanteet koulussa tai työpaikalla toistuvat. Kiusaamissuhdetta tarkastellessamme lähtökohtanamme on, että vuorovaikutussuhdetta rakennetaan ja ylläpidetään viestinnällä, ja viestinnän kautta määrittyy myös kyseisen suhteen luonne (Littlejohn 1999, 252). Kun yksilöiden välille muodostuu vuorovaikutussuhde, synnyttää se yhteisiä merki- 
tyksiä ja tulkintoja ja sitä kautta suhteen omaleimaisen "kulttuurin" (Wilmot 1996; Wood 1996). Baxter (2004) kuvaa vuorovaikutussuhdetta vastavuoroisena ja dynaamisena prosessina, johon suhteen molemmat osapuolet vaikuttavat. Sovellettaessa tätä kiusaamissuhteisiin voidaan siis ajatella, että kiusaamissuhteen osapuolten vastavuoroisen viestinnän johdosta jokaisesta kiusaamissuhteesta muodostuu omanlaisensa. Osapuolet myös tulkitsevat toistensa viestejä suhteensa historian valossa.

Emme vielä tiedä, kuinka läheisestä tai etäisestä vuorovaikutussuhteesta kiusaamissuhteessa on kyse. Vaikka kiusaamissuhde on ongelmallinen ja ei-toivottu, ovat sen osapuolet usein päivittäin ja pitkäaikaisesti tekemisissä keskenän, osittain toki olosuhteiden pakosta. Joissakin tapauksissa he voivat jopa olla riippuvaisia toisistaan esimerkiksi toisiltaan saamansa opiskeluun tai työhön liittyvän informaation vuoksi.

Tarkoituksellinen loukkaaminen vaatii tietoa toisesta ihmisestä tai esimerkiksi tälle tärkeistä asioista, kuten tämän osaamisesta, kiiinnostuksen kohteista tai perhesuhteista. Kiusaamissuhteen kehittyminen edellyttää siten ainakin jonkin verran vastavuoroista itsestäkertomista tai aktiivista tiedonhankintaa. Kiusaamisessa hyökkäyksen ja arvostelun kohteeksi voi joutua esimerkiksi kiusatun yksityiselämä, joten kiusaajaksi koetulla täytyy olla käytettävissään sitä koskevaa tietoa.

On myös selvittämättä, kuinka aktiivisena vuorovaikutussuhteena kiusaamissuhde voidaan nähdä. Kenties kiusaamissuhteen ylläpitämisessä törmätään kiusaajan ja kiusatun viestintäkäyttäytymisen ristiriitaan: toisen pyrkiessä ylläpitämään kiusaamissuhdetta kiusaamalla, voi toinen pyrkiä vetäytymään suhteesta. Pohdimme seuraavassa luvussa kiusaamissuhteen ylläpitämistä.

\section{Kiusaaminen ei-toivottuna vuorovaikutussubteena}

Usein puheviestinnän tutkimuksessa on lähtökohtaisena oletuksena, että meitä ympäröivät vuorovaikutussuhteet lisäävät hyvinvointiamme 
ja että suhteita ylläpidetään vapaaehtoisesti. Vuorovaikutussuhteiden tutkimuksessa on kuitenkin tapahtunut tällä vuosituhannella näkökulman laajennus. Tutkimuksen kohteeksi on nyt otettu myös sellaisia asetelmia, joissa vuorovaikutussuhteet eivät syystä tai toisesta ole haluttuja tai vapaaehtoisuuden pohjalta muodostettuja. (Dindia 2003, 20-22; Hess 2003,104 .) Tällaisille ei-toivotuille vuorovaikutussubteille on tyypillistä, että ainakin suhteen toinen osapuoli uskoo, ettei hänellä ole muuta vaihtoehtoa kuin ylläpitää suhdetta.

Kiusatuksi itsensä kokeva ihminen on ajautunut tällaiseen ristiriitaiseen tilanteeseen: hän joutuu olosuhteiden pakosta ylläpitämään vuorovaikutussuhdetta henkilöön, josta ei pidä ja jonka käyttäytyminen on uhkaksi hänen hyvinvoinnilleen. Tämä kokemus voi kenties päteä kiusaamissuhteen kaikkiin osapuoliin.

Ei-toivotut vuorovaikutussuhteet ovat yksi esimerkki niistä erilaisista vuorovaikutussuhteista, joita meillä on. Todennäköisesti useimmilla on esimerkiksi sukulaisuussuhde, jota ylläpidetään, vaikka suhteen toinen osapuoli ei olisi millään tavoin merkittävä ja/tai pidetty (Hess 2000, 460; 2003, 104-107). Ei-toivotut vuorovaikutussuhteet eivät toki sellaisenaan ole haitallisia osapuolille. Vuorovaikutussuhde voi kuitenkin osoittautua haitalliseksi, mikäli sen ylläpitämisessä ilmenevä vuorovaikutus uhkaa osapuolten hyvinvointia (Kinney 1998). Yhtenä ääriesimerkkinä tällaisesta ei-toivotusta vuorovaikutussuhteesta on pakkomielteinen vainoaminen (stalking, obsessive relational intrusion, Cupach \& Spitzberg 2004).

Ei-toivotut vuorovaikutussuhteet tarjoavat mielenkiintoisen näkökulman kiusaamisen tarkasteluun. Kaikki ei-toivotut vuorovaikutussuhteet eivät ole kiusaamista, mutta kiusaamista voidaan tarkastella luonteeltaan ei-toivottuna vuorovaikutussuhteena. Oletettavasti kaikki merkittävät vuorovaikutussuhteemme aiheuttavat aika ajoin mielipahaa. Kiusaaminen voidaan kuitenkin nähdä vuorovaikutussuhteena, jossa mielipaha ja ahdistus ovat suhteelle leimallisia ominaisuuksia. Kiusaamisen näkökulmas- 
ta tarkasteltuna ei-toivotuissa vuorovaikutussuhteissa olennaiseksi muodostuu nimenomaan se, miten suhdetta ylläpidetään. Kiusaamissuhdetta voidaan todennäköisesti ylläpitää moninaisin keinoin samoin kuin mitä tahansa ei-toivottua vuorovaikutussuhdetta.

Kuten ei-toivotut vuorovaikutussuhteet myös kiusaamissuhde todennäköisesti loppuisi, ellei sitä ympäröisi joukko tekijöitä, jotka pitävät suhdetta koossa. Koulun ja työn ulkopuolella meillä voi olla mahdollisuus lakata tapaamasta henkilöä, josta emme pidä tai jonka kanssa ajaudumme toistuvasti konflikteihin. Koulussa ja työssä tämä ei useinkaan ole mahdollista ilman, että se vaikuttaisi myös muihin vuorovaikutussuhteisiimme ja/tai työskentelyymme koulu- tai työtehtäviemme parissa. Koululuokkaa ei useinkaan voi vaihtaa, eikä luokan vaihtaminenkaan tuo aina toivottua muutosta. Työpaikalla kaksi henkilöä voi joutua työskentelemään samassa tiimissä pitkiäkin aikoja.

Hess (2003) on eritellyt niitä keinoja, joilla ihmiset voivat pyrkiä selviytymään ei-toivotuissa vuorovaikutussuhteissa silloin, kun fyysinen etäisyys toiseen osapuoleen ei ole mahdollista. Tuolloin etäisyyttä pyritään luomaan muilla tilanteessa käytettävissä olevilla keinoilla. Pakolliset vuorovaikutustilanteet voidaan esimerkiksi pyrkiä pitämään niin lyhyinä kuin mahdollista tai toisen osapuolen läsnäolo voidaan jättää huomioimatta erilaisin verbaalisin ja nonverbaalisin keinoin (esim. itsestä kertomista ja katsekontaktia välttelemällä). Työpaikallaan kiusatuksi itsensä kokevan lausahdus "me ei vaan kommunikoitu" (Rainivaara 2004, 80) ilmentää yhtä tapaa selvitä kiusaamissuhteessa. Vuorovaikutuksen välttely voidaan nähdä selviytymiskeinona mutta myös ei-toivotun vuorovaikutussuhteen ylläpitämisenä. Kiusaamissuhteen osapuolet voivat ajatella, ettei suhdetta ole lainkaan olemassa, jos he esimerkiksi eivät puhu toisilleen. Kuitenkin mykkäkoulun pitäminen on hyvin vahva viesti sïtä, miten toiseen osapuoleen suhtaudutaan.

Ei-toivottujen vuorovaikutussuhteiden näkökulma ei ole kiusaamisen tarkastelussa täysin ongelmaton, esimerkiksi kun pohditaan, kenen 
näkökulmasta suhde on ei-toivottu tai millaisia strategioita osapuolet käyttävät ylläpitääkseen suhdetta. Vaikuttaa siltä, että esimerkiksi koulumaailmassa kiusaaja voi hakeutua kohteensa seuraan hyvinkin aktiivisesti päästäkseen toteuttamaan tavoitteitaan. Koulukiusaaminen voidaankin nähdä ei-toivottuna vuorovaikutussuhteena selkeämmin nimenomaan kiusatun näkökulmasta.

Ensi silmäyksellä näyttää siltä, että kiusaamisprosessi niin kouluissa kuin työpaikoilla koostuu vuorovaikutuksesta, joka pyrkii ainoastaan hajottamaan ja loukkaamaan. Kiusaamissuhteista on vaikea havaita kovinkaan paljon sellaista vuorovaikutusta, joka rakentaisi ja ylläpitäisi suhdetta myönteisellä tavalla. Suhteilla ei sïs perinteisessä mielessä näyttäisi olevan rakennusaineita vahvaan ja myönteiseen kehitykseen. Tästä huolimatta kiusaamissuhteet koulussa ja työpaikalla voivat jatkua vuosia.

Olisi mielenkiintoista selvittää tarkemmin, millaisista osapuolten välisistä kohtaamisista kiusaamissuhde kaiken kaikkiaan koostuu. Koska vuorovaikutussuhteet ovat dynaamisia, voidaan olettaa, että kiusaamissuhteissa voi olla myös valoisampia hetkiä. Todennäköisesti myöskään kaikki osapuolten kohtaamiset eivät ole kiusaamista. Koulussa ja työpaikalla kiusaamissuhteen osapuolet voivat esimerkilksi monella tavalla osoittaa yhteistyöhalukkuutta työskennellessään yhteisten tehtävien parissa. Pois ei kenties voida sulkea sitäkään, että osapuolet voivat pyrkiä ratkaisemaan niitä konflikteja, joita ongelmallisessa vuorovaikutussuhteessa esiintyy.

\section{Kinsaamisen muodot vuorovaikutussubteessa}

Kiusaaminen on usein operationaalistettu kiusaamisteoiksi, mutta on mahdotonta kirjoittaa tyhjentävää kuvausta viestinnästä, joka voidaan selkeästi nimetä kiusaamiseksi tai joka voidaan kokea kiusaamisena. Koulukiusaamisen yhteydessä puhutaan usein kiusaamisen suorista ja epäsuorista muodoista. Suorina muotoina nähdään esimerkiksi fyysinen 
väkivalta, tavaroiden rikkominen, haukkuminen ja nimittely. Hyöklä̈ys voi kohdistua myös kiusatun koulutyöhön. Hänen piirustuksiaan voidaan sotkea, koulukirjoja tärvellä tai hänen osuuttaan esimerkiksi ryhmätöissä voidaan vähätellä. Tällä tavoin kiusaaja voi vaikeuttaa uhrinsa koulutyötä ja/tai opintomenestystä. Epäsuorana kiusaamisena pidetään puolestaan esimerkiksi kiusatusta pahan puhumista tämän selän takana sekä kiusatun eristämistä muusta oppilasryhmästä. Kiusattua vahingoitetaan kiertoteitse, mistä johtuen epäsuoran kiusaamisen ajatellaan. usein olevan vaikeammin havaittavaa kuin suoran kiusaamisen. (Olweus 1992, 14-15; Salmivalli 1998, 35-36.)

Puheviestinnän näkökulmasta koulukiusaamisen muotojen jako suoriin ja epäsuoriin voi olla haasteellista. Jotkut suoran kiusaamisen muodot, kuten uhkailu tai toisen alistaminen, voivat olla niin sanatonta kuin sanallistakin viestintää. Sanattomasti ilmenevää kiusaamista, kuten vihaisia katseita, voi esimerkiksi opettajan olla vaikea havaita. Myös osa sanallisista loukkaavista viesteistä voi olla hyvinkin taidokkaasti rakennettuja hienovaraisia loukkauksia, joita ulkopuolisen ei ole helppo havaita (Karhunen 2004, 89-90).

Käytetyimpien määritelmien mukaan työpaikkakiusaaminen on toimintaa, jossa pyritään joko käyttäytymään ikään kuin työtoveri ei olisi paikalla tai vastavuoroisesti häneen kiinnitetään kielteistä huomiota normaalia enemmän (Reinboth 2006, 63). Työtovereiden toisiinsa kohdistama fyysinen väkivalta on hyvin harvinaista (Einarsen ym. 2003b, 9), mutta kiusaamiseksi koettu viestintä voi myös työpaikalla ilmetä verbaalisesti aggressiivisina uhkauksina. Yhtä lailla loukata voidaan ilman näkyvää verbaalista aggressiivisuutta tai vihan osoittamista (Rayner \& Cooper 2006, 125).

Työpaikallaan kiusatuksi itsensä kokevan persoonallisuus, mielenterveys, luotettavuus ja ammattiosaaminen voivat joutua toistuvan arvostelun kohteeksi kasvotusten tai kiusatun selän takana. Työntekijä voi kokea joutuneensa eristetyksi muusta työyhteisöstä (esim. hänelle ei 
puhuta tai hänen työpisteensä siirretään muista erilleen), hänen yksityiselämäänsä voidaan arvostella tai pilkata ja hänen työtehtäviään voidaan vaikeuttaa tietoa pimittämällä sekä työn määrää manipuloimalla (esim. osoittamalla hänelle liian vähän tai liian paljon työtehtäviä). Kiusatuksi itsensä kokevan työsuorituksia myös arvostellaan toistuvasti ja perusteettomasti. (Einarsen ym. 2003b, 9.)

Kiusaamiselle on ominaista viestintäkäyttäytymiselle annettujen tulkintojen moninaisuus. Ihmiset loukkaantuvat erilaisista asioista, mikä asettaakin haasteita esimerkiksi kiusaamisen tunnistamiseen ja sibhen puuttumiseen. Seuraavissa luvuissa pohdimme tarkemmin tulkintojen merkitystä kiusaamissuhteessa sekä kiusaamisen tunnistamisen haasteita. Tunnistaminen liittyy läheisesti kiusaamisen tunnustamiseen ja siihen puuttumiseen.

\section{Kiusaaminen, tietoisuus ja tulkinta}

Merkittävä ero koulu- ja työpaikkakiusaamisen määritelmissä on, miten tietoisena ja tarkoituksellisena ilmenevä loukkaava viestintä nähdään. Koulukiusaamisen yhteydessä puhutaan usein tavoitteellisesta ja tietoisesta toisen ihmisen satuttamisesta (Olweus 1992, 14-15; Salmivalli 1998, 30-31; 2003, 11), ja monissa koulukiusaamisen määritelmissä tietoisuus mainitaan yhtenä kiusaamisen keskeisenä tunnuspiirteenä (Pörhölä, Karhunen \& Rainivaara 2006, 259-260).

Tavoitteellisuus ja tietoisuus eivät sen sijaan liity työpaikalla esiintyvän kiusaamisen määritelmiin yhtä yksiselitteisesti (Pörhölä, Karhunen \& Rainivaara 2006). Työpaikkakiusaamisen tarkastelun keskiössä on kiusatuksi itsensä kokevan tulkinta siitä, mitä kiusaaminen on. Näin ajateltuna vain viestinnän, jonka kiusaamisen kohde itse tulkitsee loukkaavaksi, voidaan ajatella olevan kiusaamista (esim. Hoel, Faragher \& Cooper 2004, 369; Rayner \& Cooper 2006, 126). Teot satuttavat, vaikka ne kiusaajana pidetyn näkökulmasta eivät kiusaamista olisikaan (Einarsen ym. 2003b, 12). 
Tulkinnallisuuden ongelma tulee esiin myös esimerkiksi silloin, kun esimiesten on oltava kriittisiä alaistensa työpanosta kohtaan. Nämä viestit voidaan tulkita uhkaaviksi, vaikka palaute annettaisïnkin kaikkia kohteliaan käytöksen ja rakentavan palautteenannon sääntöjä noudattaen. Käytännössä voi silti olla haasteellista erottaa, milloin arvostellaan työtä ja milloin sen tekijää. (Kinney 2006, 180.) Rajanveto on haasteellista myös pohdittaessa, milloin kyseessä on esimiehen legitiimi oikeus tehdä alaisensa työhön liittyviä päätöksiä ja milloin taas valta-aseman väärinkäyttö ja kiusaaminen. Samanlainen viestintä voidaan tietyssä tilanteessa kokea kiusaamisena, toisessa ei. Liefooghen ja Olafssonin (1999, 40-48) mukaan kyseessä on ilmiö, josta tehdyistä tulkinnoista yksi on kiusaaminen. Yksilö siis ikään kuin valitsee omansa eri tulkintavaihtoehtojen väliltä. Loukkaava vuorovaikutus kiusaamissuhteissa ei läheskään aina ole tunnistettavissa, tulkittavissa saati tutkittavissa vain ilmiasunsa kautta.

Työyhteisökonfliktien sovittelukeskusteluissa useammat osapuolet voivat ilmaista tulleensa syvästi loukatuksi ongelmallisessa vuorovaikutussuhteessa (Vartia ym. 2003, 287-289). Roolijaon tekeminen kiusaajan ja kiusatun välille ei sekään ole aina yksiselitteistä. Työpaikalla loukkaantumisen osoittaminen, kuten kiusaajaksi koetun sanoihin tai tekoihin vastaaminen verbaalisella aggressiolla, voi työtoverin tai esimiehen näkökulmasta näyttää yhtä lailla epäasialliselta käyttäytymiseltä. Ulkopuolisen voikin olla vaikea nähdä, kumpaa tilanteessa lopulta kohdellaan epäasiallisesti. Joskus myös stressaantuneen ja turhautuneen kiusatun äänekäs tapa hakea tukea työtovereiltaan voi työtovereiden silmissä näyttäytyä epäasiallisena käyttäytymisenä eikä halukkuutta tuen osoittamiseen synny (esim. Einarsen \& Mikkelsen 2003, 137).

Koulussa ja työpaikalla kukin tulkitsee näkemiään tapahtumia omaan merkitysperspektiiviinsä sidottuna ja näin ollen myös tulkinnat samoista vuorovaikutustilanteista saattavat vaihdella eri osapuolten välillä. Karhunen (2006) tarkasteli nuorten kirjoittamia koulukiusaamiskerto- 
muksia ja havaitsi nuorten selittävän kiusaamista sekä sen syitä hyvin eri tavoin. Koulukiusaamiselle annetut attribuutiot vaihtelivat riippuen siitä, kenen näkökulmasta nuoret kuvasivat tapahtumia ja olivatko he henkilökohtaisesti olleet jollakin tavalla mukana kiusaamisessa. Näin ollen esimerkiksi koulukiusaamistilanteita selvittelevä opettaja saattaa kohdata hyvinkin erilaisia kuvauksia siitä, mitä kiusaamistilanteissa oikeastaan on tapahtunut. Jokainen samaa kiusaamistilannetta kuvaava oppilas uskoo oman näkemyksensä totuudellisuuteen. Näin ollen erilaisten totuuksien yhteensovittamisesta voi tulla haasteellinen tehtävä.

Teräsahjo ja Salmivalli (2002) havaitsivat koulukiusaamisen tulkintarepertuaareja tarkastelevassa diskurssianalyyttisessä tutkimuksessaan kolme puhetapaa, joita lapset käyttivät puhuessaan koulukiusaamisesta. Näistä ensimmäisessä kiusaaminen näyttäytyi tahallisena ja paheksuttavana yrityksenä tehdä pahaa toiselle. Toisena esillä olivat puhetavat, joissa kiusaaminen koulussa näyttäytyi pikemminkin edellisen vastakohtana. Tällöin kiusaamista saatettiin vähätellä tai selittää esimerkiksi ystävyyssuhteiden oikuilla. Kolmantena korostuivat kiusaamista oikeuttavat puhetavat. Kiusattu saatettiin esimerkiksi määritellä erilaiseksi tai ärsyttäväksi, jolloin kiusattu ikään kuin ansaitsi kielteisen kohtelun. Teräsahjon ja Salmivallin tutkimus havainnollistaa sitä, miten oma osallisuus kiusaamisessa ei ole aina oppilaille selvä. Kiusaamisesta syytetty ei välttämättä pysty tai halua nähdä omaa osallisuuttaan tapahtumiin vaan selittää omaa toimintaansa esimerkiksi kiusatusta johtuvaksi.

\section{Kiusatun viestintä ja selviytyminen}

Kiusaamistutkimus perustuu toistaiseksi, erityisesti työpaikan kontekstissa, kiusattujen kokemuksiin. Kiusaamissuhteen kehittymisen ja ylläpitämisen tarkastelumme pohjautuukin pitkälti siihen, mitä tiedämme kiusaamisen kohteen viestinnästä ja selviytymisestä. Tässä luvussa keskitymme tarkemmin kiusatuksi itsensä kokevaan.

Koulukiusaamisen uhreja on usein tunnistettu joko itse- tai vertais- 
arvion avulla (Salmivalli 1998, 98). Toisinaan näiden arvioiden tulokset on yhdistetty siten, että kiusatuiksi katsotaan ne lapset ja nuoret, jotka identifioituvat kiusatuiksi sekä omissa että koulutoveriensa arvioissa. Työpaikkakiusaamisen tutkimuksissa vertaisarviointia on käytetty jonkin verran (esim. Coyne, Craig \& Smith-Lee Chong 2004), mutta pääsääntöisesti on jäänyt kiusatuksi itsensä kokevien omien arvioiden varaan, näkevätkö myös työtoverit heidät kiusattuina.

Kiusattuja ja heidän tapaansa toimia kiusaamistilanteissa voidaan tarkastella esimerkiksi kiinnittämällä huomiota siihen, miten kiusatut pyrkivät toimimaan kiusaamistilanteissa, millaisia sisäisiä selviytymiskeinoja he käyttävät tai miten aktiivista tai passiivista heidän toimintansa on.

Salmivalli, Karhunen ja Lagerspetz (1996, 107-108) ovat havainneet, että koulukiusaamistilanteissa kiusatut ilmaisevat suoraan haavoittuvuutensa, vastaavat aggressiivisesti tai pyrkivät käyttäytymään välinpitämättömästi. Nämä luokittelut tosin kuvaavat vain kiusattujen ulkoista käyttäytymistä, eivät heidän subjektiivista tunnetilaansa tai ajatuksiaan. Vaikka kiusattu vaikuttaisikin siltä, että hän ei välitä kiusaamisesta, on välinpitämättömyys vain hänen välittämänsä viesti. Kiusaaminen satuttaa riippumatta siitä, miten kiusattu puolustautuu. (Salmivalli 1998, 107.)

Työpaikalla työntekijä voi vastata kolkemiinsa loukkauksïn rauhanomaisemmin (sovittelemalla, anteeksi antamalla) tai vihamielisemmin (esim. kostamalla) (Aquino, Bies \& Tripp 2006) ja vaikuttaa kenties riitatilanteen etenemiseen. Yleisempää työpaikan arjessa on, että ristiriidat ratkeavat itsestään. Kiusaamisprosessin eteneminen kuitenkin nähdään työpaikkakiusaamisen nykytutkimuksessa nimenomaan ratkaisematta jääneen ristiriidan aiheuttamana konfliktikierteenä. Tätä prosessia kuvaavan mallin mukaan konfliktista alkunsa saanut noidankehä voi ajan myötä ajaa toisen osapuolen heikompaan asemaan ja jopa kiusatuksi. (Alberts, Lutgen-Sandvik \& Tracy 2005; Andersson \& Pearson 1999; Aquino, Bies \& Tripp 2006.) Prosessimallit ovat kuitenkin varsin ho- 
mogeenisia kuvauksia kiusaamiseen johtavien prosessien etenemisestä. Ne kuvaavat lähinnä epäasiallisen kohtelun kehityskaarta, jossa loukkaaminen saa jatkuvasti vakavampia muotoja ja johtaa lopulta kiusaamiseen. Prosessimalli ei sen sijaan kuvaa esimerkiksi vuorovaikutuksen dynamiikkaa tai miten hyökkäyksen kohteena oleva puolustautuu.

Toinen tapa tarkastella sitä, miten kiusatut toimivat jouduttuaan kielteisen kohtelun kohteeksi, on tutkia heidän käyttämiään selviytymiskeinoja. Coping-käsitteellä tarkoitetaan sitä selviytymisprosessia, jolla yksilö pyrkii kognitioidensa ja käyttäytymisensä kautta hallitsemaan ja vähentämään jonkin tekijän kielteisiä ja stressaavia vaikutuksia. Selviytymiskeinot voivat vaihdella muun muassa aktiivisesta ja suunnitelmallisesta ongelmanratkaisusta sosiaalisen tuen hakemiseen, oman käyttäytymisen ja itsetunnon hallintayrityksiin sekä ongelmatilanteen kieltämiseen tai välttelyyn. (Lazarus 1993, 237.) Työpaikalla kiusatuksi itsensä kokevat pyrkivät selviytymään esimerkiksi moninaisten sisäisten selitysmalliensa avulla (esim. Hogh \& Dofradottir 2001; Ólafsson \& Jóhannsdóttir 2004; Zapf \& Gross 2001).

Kiusattujen toimintaa voidaan myös tarkastella arvioimalla sitä, miten aktiivisesti tai passiivisesti he pyrkivät ratkaisemaan kohtaamansa ongelman. Työpaikallaan kiusatun toiminta on toistaiseksi nähty jokseenkin mustavalkoisesti, joko aktiivisena tai passiivisena. Vaikuttaa kuitenkin siltä, että nämä eivät ole keskenään vaihtoehtoisia vaan osittain samanaikaisia toimintatapoja. Työpaikallaan kiusatut ovat useimmiten aluksi aktiivisempia ratkaisemaan ongelmatilanteita esimerkiksi keskustelemalla heitä loukanneen osapuolen tai esimiehensä kanssa. Mikäli tämä ei tuota toivottua lopputulosta, voi kiusattu turvata itsensä vetäytymällä - viime kädessä irtisanoutumalla. (Ólafsson \& Jóhannsdóttir 2004; Zapf \& Gross 2001.) Passiivisuus siis myös kuvastaa, valitettavasti, kiusatun voimavarojen vähenemistä, kun ongelman esille nostaminen ei yrityksistä huolimatta johda toivottuihin toimenpiteisiin. Toisaalta irtisanoutuminen voidaan nähdä hyvinkin aktiivisena vastatoimenpiteenä 
kiusaamiselle (esim. Lutgen-Sandvik 2006).

Parisuhdeväkivallan uhreja tutkinut Husso (2003, 55-57) ei kannata uhrien arvottamista joko aktivisiin tai passiivisiin. Uhrin toiminnassa aktiivisuus ja passiivisuus voidaan nähdä vaihtoehtoisuuden sijaan yhtäaikaisina kokemuksina. Tämä näkemys varmasti pätee pitkälti myös koulussa tai työssään kiusattuun. Uhri voi siis samanaikaisesti olla myös selviytyjä.

Ongelmallinen ilmiö koulussa tai työpaikalla kiusatun viestintäkäyttäytymiseen liittyen on provokaatio. Provokaatio ei ole edellytys kiusaamiselle, mutta joskus uhri voi käyttäytyä provokatiivisesti tietoisesti tai tiedostamattaan (esim. Olweus 1992, 34-35; Vartia 2003, 14-16). Olweuksen $(1992,34)$ mukaan koulukiusaamisen uhrit voidaan jakaa kahteen eri tyyppiin: passiiviseen ja provokatiiviseen uhriin. Passiivinen uhri viestii ulospäin avuttomuutta, turvattomuutta ja kyvyttömyyttä puolustaa itseään. Tämä voi houkuttaa ja palkita kiusaajaa. On silti muistettava, että puolustuskyvyttömältä vaikuttava lapsi (tai aikuinen) voi olla hyvinkin aktiivinen etsiessään tietoa ja tukea ympäristöstään.

Provokatiivinen koulukiusattu saattaa käyttäytymisellään ärsyttää muita ympärillään olevia sekä olla itsekin aggressiivinen ja kiusata muita. Tällainen käyttäytyminen provosoi luokkatovereita ja voi luokkatovereiden näkökulmasta oikeuttaa uhrin kiusaamisen. Provokatiivisia kiusattuja on kuitenkin huomattavasti vähemmän kuin passiivisia kiusattuja. (Olweus 1992, 35.)

Työpaikkaa koskevat tutkimukset antavat viitteitä siitä, että provokaationa voidaan nähdä esimerkiksi se, jos työntekijä korostaa toistuvasti omaa osaamistaan ja ahkeruuttaan muihin nähden (Brodsky 1976, Vartian 2003, 15 mukaan). Kusaamisen kohteet selittävät kiusaamista useimmiten kiusaajansa ominaisuuksista ja henkilökohtaisista ongelmista, kuten kateudesta ja huonosta itsetunnosta, johtuvana (esim. Björkvist, Österman \& Hjelt-Bäck 1994). On myös mahdollista, että kiusaaminen synnyttää noidankehän, jolloin on vaikea sanoa, onko esimerlkiksi kiusa- 
tun masennus kiusaamisen seuraus vai sen syy. Näin voi käydä esimerkiksi, jos kiusattu uupuu ja muu työyhteisö syyllistää häntä (kiusaamalla) joutuessaan vastaamaan tämän työtehtävistä (Vartia 2003, 51).

Kiusaamisen selittäminen kohteeksi joutuneen ominaisuuksilla on monin tavoin ongelmallista. Leymann (1996) esittää, että uhrin mahdollinen aggressiivinen reaktio on vain normaali tapa reagoida häntä kohdanneeseen epänormaaliin tilanteeseen, ei syy kiusaamiselle. Kiusaamisen syyn etsiminen kiusaamisen kohteesta voi myös luoda sen vaikutelman, että on olemassa käyttäytymistä, joka johtaa kiusaamiseen. Onko kiusaaminen tällöin "ruotuun palauttava" toimenpide normeja rikkoneelle yksilölle, joka vaikeuttaa työskentelyä luokassa tai työpaikalla, vai jotain muuta? Mikäli vastaus tähän olisi löydettävissä, voitaisiin samalla osoittaa, millainen viestintä suojaa kiusaamiselta.

Koulu- ja työpaikkakiusaamista käsittelevän kirjallisuuden perusteella on vaikea viime kädessä erottaa, milloin tarkastellaan kiusatun selviytymiskeinoja, milloin puolustautumista ja milloin taas kyseessä voidaan ajatella olevan kiusaamissuhteen ylläpitämisen näkökulmasta tarkasteltava vuorovaikutus. Esimerkiksi passiivisuus ja vetäytyminen voivat olla sekä tapa selviytyä suhteessa että ylläpitää sitä. Puolustautumista voidaan tarkastella myös provokaationa tai yhtä lailla kiusaamisena.

\section{Kiusaamissuhdetta ympäröivä ybteisö}

Kiusaamissuhteen osapuolet eivät ylläpidä suhdettaan irrallisena sitä ympäröivästä koulu- tai työyhteisöstä. Kiusaamissuhteen taustalla voi vaikuttaa kiusaajaa ja kiusattua ympäröivä ryhmä, joka voi tietynlaisin sanoin ja teoin palkita tai tuomita suhteessa esiintyvän vuorovaikutuksen. Esimerkiksi koululuokkien välillä on havaittu olevan eroja sïnä, miten tyypillistä on asettua kiusaamistilanteessa kiusaajan tai kiusatun puolelle (Salmivalli \& Voeten 2004). Yhteisö saattaakin tukea toiminnallaan kiusaamissuhteen ylläpitämistä, ei sen lopettamista.

Tämä havainnollistaa kiusaamiskokemuksen luonnetta: se määrittyy 
toisaalta sekä yksilöstä itsestään että häntä ympäröivästä yhteisöstä käsin. Tällöin tulkintaeroja syntyy väkisin. Kiusaaminen on myös ryhmäprosessi; kiusaajan ja kiusatun roolit ovat yhteisössä, eivät vain kiusaamissuhteessa, muodostuneita.

Hamaruksen (2006) väitöskirjatutkimus tarjoaa näkökulmia koulukiusaamiseen yhteisöllisenä ilmiönä suomalaisessa kulttuurissa. Hän tarkastelee nuorten kokemuksia koulukiusaamisesta sosiaalisesta ja kulttuurisesta näkökulmasta. Hän näkeekin kiusaamisen nimenomaan keinona tuottaa ja vahvistaa oppilaskulttuuria. Erilaiset teot ja toimintatavat tuottavat kiusaajaryhmään sisäistä yhtenäisyyttä yhden jäsenen kustannuksella. Kiusaamisen sosiaalisen ja kulttuurisen luonteen vuoksi kiusaaminen ei rajoitu ainoastaan kouluun, vaan kulkeutuu tehokkaasti myös sen ulkopuolelle. Hamarus korostaa kiusaamisen olevan syvästi kietoutunut suhteisiin, joten ilmiön tunnistaminen vaatii yhteisön jäsenten välisten suhteiden, kulttuuristen merkitysten ja oppilaiden välisen vuorovaikutuksen tuntemusta.

Myös työyhteisö voi mukautua tietoisesti tai tiedostamattaan kiusaajaksi koetun viestintäkäyttäytymiseen. Esimerkiksi Hearn ja Parkin $(2002,47)$ toteavat, että sukupuolinen häirintä, kiusaaminen ja fyysinen väkivalta työssä eivät tapahdu sattumalta, vaan ne muodostuvat monimutkaisissa yhteisöllisissä prosesseissa, joissa liikuttavina voimina ovat ilmiöiden tunnistaminen ja tapa suhtautua niihin.

Kiusaamiseen puuttuminen edellyttää kiusaamisen tunnistamista ja tunnustamista ympäröivän yhteisön taholta. Työyhteisö ei aina kuitenkaan pidä kiusatun mielestä loukkaavaa käytöstä norminvastaisena eikä kiusaaja tällöin saa palautetta käytöksestään. (Neuman \& Baron 2003, 185-186; Richards \& Daley 2003.) Juoruilua, toisten kustannuksella naureskelua tai yksilön tiettyä ominaisuutta kuvaavien lempinimien käyttämistä voidaan pitää vuorovaikutussuhteen ylläpitämisen harmittomana keinona (esim. Michelson \& Mouly 2004). Juorujen ja lempinimien kohde voi kuitenkin kokea tämän kiusaamisena. 
Voidaan sïs ajatella, että kiusaamista arvioidaan erilaisella normistolla kuin muunlaista aggressiivista käyttäytymistä. On helppo olla samaa mieltä siitä, että heikompaa osapuolta kohtaan ei tulisi hyökätä tai että epäasiallinen käyttäytyminen koulussa tai työpaikalla ei ole sallittua. Esimerkiksi työpaikalla tämä normi saattaa kuitenkin kääntyä päälaelleen eikä esimerkiksi heikomman alistamista enää pidetäkään yksiselitteisesti norminvastaisena ja epäeettisenä tekona (Neuman \& Baron 2003, 185-186).

Joissain työyhteisöissä aggressiivinen käyttäytyminen työtoveria kohtaan voi olla sallittua myös tietoisesti, vaikka aggressiivista kulttuuria ei sinänsä pyrittäisikään luomaan. Aggressiivisen työskentelykulttuurin voidaan katsoa syntyvän sivutuotteena erityisesti niillä aloilla (esim. armeijassa), joille on leimallista tarkka käyttäytymissäännöstö, perinteet sekä vahva hierarkia. Muun muassa simputtaminen on osa kulttuuria, jota ylläpidetään, johon kaikkien edellytetään mukautuvan ja jota jaetaan eteenpäin "kulttuuriperintönä" uusille tulokkaille. (Esim. Archer 1999.)

Kiusaaminen koetaan usein häpeällisenä kokemuksena, eikä siitä välttämättä haluta tai uskalleta puhua ääneen tai kertoa ulkopuolisille. Erityisesti lasten on vaikea kertoa kiusaamisestaan opettajalle tai muille aikuisille (Whitney \& Smith 1993). Mannerheimin Lastensuojeluliiton (2006) tekemän internetkyselyn mukaan vain noin puolet lapsista kertoo kokemuksistaan vanhemmilleen. Lisäksi kiusatut eivät useinkaan usko, että kertomisesta olisi heille apua. Lasten ja nuorten vertaisryhmissä tapahtuvaa syrjintää (peer rejection) tutkineet Sunwolf ja Leets (2003) havaitsivat, että lapset eivät myöskään uskalla puolustaa ryhmän ulkopuolelle jätettyä, koska he pelkäävät jäävänsä itse sen seurauksena ryhmän ulkopuolelle. Moni lapsi myös uskoo, että kiusaamiseen mukaan meneminen takaa sen, että tulee itse hyväksytyksi ryhmässä (Salmivalli 2003, 34).

Työpaikkakontekstissa yhtenä kiusaamiskokemuksista kertomista 
helpottavana tai vaikeuttavana tekijänä voivat olla organisaatiotason diskurssit, jotka kuvastavat yleistä suhtautumista kiusaamiseen tai esimerkilksi sukupuoliseen häirintään ja siitä puhumiseen. Clairin (1993, 124-131) tutkimuksessa tarkasteltiin niitä puhetapoja, jotka pitävät yllä sukupuolisen häirinnän mahdollistavia valtarakenteita organisaatioissa. Clair näkee, että organisaation jäsenten puhetavat ja heidän toisilleen kertomansa tarinat sukupuolisesta häirinnästä saattavat pitää yllä jo olemassa olevia valtarakenteita ja sitä kautta entisestään luoda lisää tilaa ja mahdollisuuksia sukupuoliselle häirinnälle. Näin ollen työpaikallaan härinnän kohteeksi joutuneet naiset saattavat tuomita saamansa kohtelun mutta silti ylläpitää olemassa olevia käytänteitä omalla puhetavallaan. Häirinnän kohteeksi joutuneet voivat vähätellä kokemuksiaan tai pitää niitä vahinkoina. Omaa kokemusta ei välttämättä osata (tai haluta) nimetä häirinnälksi.

Tyypillistä on myös, että organisaation etu asetetaan oman edun edelle. Sukupuolisen häirinnän kohde voi esimerkiksi ajatella, että esimiehelle ja yritykselle koituu enemmän harmia, jos hän nostaa häirinnästä syytteen. (Clair 1993, 124-131.) Samoin työssään itsensä kiusatuksi kokeva voi pelätä leimautuvansa hankalaksi työntekijäksi (Liefooghe \& Olafsson 1999, 45-46) ja kiusaamisen pahenevan entisestään, jos siitä kertoo esimerkiksi esimiehelle (Lutgen-Sandvik 2006, 425).

Kiusaaminen on kiusallinen ongelma niin koulu- kuin työyhteisölle. Yksittäisen kiusaajaksi koetun henkilön lisäksi kiusatulla voi olla vastassaan kiusaamissuhdetta ympäröivien ihmisten joukko, jotka eivät syystä tai toisesta pysty tai halua tukea kiusaamisen loppumista. Ilmiön salailu, kieltäminen ja vähätteleminen voivat liittyä myös haluun suojella organisaatiota mahdolliselta julkisuuskriisiltä.

Organisaatiot eroavat toisistaan tavoissaan määritellä kiusaaminen sekä se, miten sihen tulisi suhtautua ja puuttua. On myös eri asia, miten kiusaamisen tuomitseminen ja siihen puuttuminen näkyvät virallisissa ohjeistuksissa ja toisaalta miten nämä todentuvat jokapäiväisessä toi- 
minnassa ja yhteisön jäsenten vuorovaikutuksessa. Se, miten kiusaamisesta puhutaan, millainen käyttäytyminen sallitaan ja kuinka avoimesti mahdollisten ongelmien esille nostamiseen kannustetaan, ovat oleellisia kysymyksiä kiusaamiseen liittyviä organisaatiotason tekijöitä tarkasteltaessa. Organisaatioissa ei useinkaan ole yhtenäistä käsitystä siitä, mistä kiusaamisessa on kyse. (Braithwaite 2001, 4; Hearn \& Parkin 2002, 48.) Tällöin työntekijöiden voi olla vaikea suhtautua työtovereidensa kuvailemiin kiusaamiskokemuksiin.

Kiusaamiskokemusta näyttääkin leimaavan tietynlainen yksinäisyys. Mikäli työpaikalla on useita, jotka kokevat tietyn ihmisen käyttäytymisen loukkaavana, voidaan selitys huonolle käyttäytymiselle herkemmin liittää tämän henkilön persoonallisuuteen tai hänelle tyypilliseen toimintatapaan kuuluvaksi.

Työpaikan vaihtaminen olisi varmin tapa turvata itsensä ongelmallisen vuorovaikutussuhteen aiheuttamalta ahdistukselta, mutta tämä ei useinkaan ole houkutteleva vaihtoehto. Työntekijä voi kiusaamisesta huolimatta pitää suuresti työstään ja olla sitoutunut työnantajaansa. Poistumalla työpaikalta hän joutuisi myös luopumaan niistä myönteisistä ihmissuhteista, joita siellä on tarjolla.

\section{JOHTOPÄÄTÖKSIÄ}

Sekä koulu- että työpaikkakiusaamisen tutkimus tarjoaa nykyisellään jo melko kattavasti vastauksia kysymykseen, millaista viestintäkäyttäytymistä kiusaaminen on. Puheviestinnän tutkimus voi täydentää tutkimuskenttää esimerkiksi tarjoamalla uusia näkökulmia koulun ja työpaikan ongelmallisten vuorovaikutussuhteiden syntyyn ja niille ominaisiin luonteenpiirteisiin.

Kiusaaminen ilmiönä on hyvin monitahoinen ja siinä yhdistyvät niin yksilö-, ryhmä- kuin yhteisötasonkin tekijät. Kiusaaminen kietoutuu vuorovaikutuksessa osaksi suhteita ja ryhmien rakenteita. Onkin 
ilmeistä, että kiusaamisen ymmärtäminen ilmiönä vaatii sen ilmitasoa syvempää tarkastelua. Olennaista on tutkia sitä, miten merkitykset ja tulkinnat rakentuvat vuorovaikutuksessa ja miten eri osapuolet ymmärtävät kiusaamisen ilmiönä.

Kiusaamissuhteen käsitteellistäminen on haasteellista, ja käsitteellistämisen mukana jotain merkittävää tutkittavan ilmiön olemuksesta tuntuu myös katoavan. Siten myös kehitteillä olevalla käsitteellä ja sen määritelmällä on omat rajoituksensa, eikä vuorovaikutuksen näkökulman sisällyttäminen kiusaamistutkimukseen ei ole ongelmatonta. Kiusaamissuhteen käsitteessä voi muun muassa piillä vaikutelma, että kiusaamissuhteen osapuolet vuorovaikutuksessaan tuottavat kiusaamisongelman tai että kiusaaminen on molemminpuolista.

Vaikka kiusaaminen sinänsä on vuorovaikutuksellinen ilmiö, ei kiusaamisen voida välttämättä katsoa edellyttävän kiusatun osallisuutta vastavuoroisella kiusaamisella, vaikka kiusattu nähdäänkin aktiivisena vuorovaikutussuhteen osapuolena. On lähes mahdotonta ottaa kantaa siihen, tuottavatko kiusaamissuhteen osapuolet ongelman vastavuoroisesti vai onko se lähtöisin yksilöstä.

Teoreettisena käsitteenä kiusaamissuhde sijoittuu yksilön ja ryhmän väliiin, eikä kiusaamissuhteen käsitteenä siten voida olettaakaan antavan vastausta siihen, missä määrin kiusaaminen on yksilöstä ja missä määrin yhteisöstä johtuvaa. Kiusaamisen tarkastelu vuorovaikutussuhteena tarjoaa kuitenkin uuden näkökulman tarkastella kiusaamisen syntyä ja sen jatkumista. Kiusaamissuhteessa esiintyvän viestintäkäyttäytymisen piirteitä tutkimalla voidaan muun muassa hahmottaa, millaisia rutiineja ja toisaalta strategisempia käytänteitä sekä käännekohtia suhteen ylläpitämiseen muodostuu sen kehityskaaren aikana.

Kiusaamisen elinkaari tuntuu tutkimuksissa päättyvän johonkin käännekohtaan, kuten opettajan puuttumiseen, työssään kiusatun irtisanoutumiseen tai sovittelukeskusteluun. Jatkossa voidaan tarkastella, miten vuorovaikutussuhde kehittyy sen jälkeen, kun kiusaaminen on 
nostettu esiin. Kïntoisa tutkimuskohde olisikin, miten kiusaamissuhteen osapuolet työskentelevät esimerkiksi sovittelukeskusteluissa ratkaistakseen ongelmansa.

Kiusaamisen vaikutuksia yksilön kannalta tulisi tarkastella edelleen myös sitä kokeneiden myöhempien elämänvaiheiden vuorovaikutussuhteissa. Lapsuuden tai nuoren aikuisuuden kiusaamiskokemusten on havaittu aiheuttavan ongelmia esimerkiksi luottamuksen ja läheisyyden muodostumisessa myöhemmissä vuorovaikutussuhteissa (Ledley ym. 2005; Pörhölä 2006). Kiusaaminen voi olla riski myös kiusaajan kehitykselle. Pepler ja Craig $(2000$, 5) näkevät kiusaamisen ilmiönä, joka ei välttämättä ole lasten ja nuorten ohimenevä kehitysvaihe, vaan pikemminkin opittu käyttäytymismalli. Se voi toistua niin kiusaajan kuin kiusatunkin myöhemmässä elämässä ongelmina pari-, perhe- ja työsuhteissa. On kuitenkin haasteellista todistaa empiirisesti, että olisi olemassa jatkumo, jossa kouluikäisenä kiusattu ajautuu kiusatuksi myös työelämässä (Smith ym. 2003). Kiusaaminen on monitahoinen prosessi, johon vaikuttavat aina lukuisat tekijät.

Artikekelin kirjoittajat tekevät väitöskirjatutkimuksiaan Suomen Akatemian rahoittamassa bankkeessa "Henkinen väkivalta vuorovaikutussụbteissa koulun ja työelämän konteksteissa" (bankenumero 107301). Kirjoittajat kizittävät Prologin päätoimittajaa ja toimituskuntaa, artikkelin arvioijaa sekä akatemiatutkija Maili Pörbölää artikkelin sisältöä Koskevista arvoke kista kommenteista. Lisäksi kirjoittajat kiütüuät lehtori Maija Karhusta ja FL Timo J. Tuikekaa artikekelin kielellistä sujuvuntta edistäneistä buomioista.

\section{KIRJALLISUUS}

Alberts, J. K., Lutgen-Sandvik, P. \& Tracy, S. J. 2005. Workplace bullying: A case of an escalated incivility. Paper presented at the International Communication Association Convention, May 26-30, New York. 
Andersson, I. M. \& Pearson, C. M. 1999. Tit for tat? The spiraling effect of incivility in the workplace. Academy of Management Review 24, 452-471.

Aquino, K., Bies, R. J. \& Tripp, T. M. 2006. Getting even or moving on? Power, procedural justice, and types of offense as predictors of revenge, forgiveness, reconciliation, and avoidance in organizations. Journal of Applied Psychology 91, 653-668.

Archer, D. 1999. "Exploring "bullying" culture in the para-military organisation. International Journal of Manpower 20, 94-105.

Baxter, L. A. 2004. A tale of two voices: Relational dialectics theory. The Journal of Family Communication 4 (3\&4), 181-192.

Beck, C. (toim.) 2006. Communication Yearbook 30. Mahwah, NJ: Lawrence Erlbaum.

Björkvist, K., Österman, K. \& Hjelt-Bäck, M. 1994. Aggression among university employees. Aggressive Behavior 20, 173-184.

Btaithwaite, R. 2001. Managing aggression. London: Routledge.

Brodsky, C. M. 1976. The harassed worker. Toronto: Lexington Books, DC Health.

Canary, D. J. \& Dainton, M. (toim.) 2003. Maintaining relationships through communication. Relational, contextual, and cultural variations. Mahwah, NJ: Lawrence Erlbaum.

Clair, R. P. 1993. The use of framing devices to sequester organizational narratives: Hegemony and harassment. Communication Monographs 60, 113-136.

Coyne, I., Craig, J. \& Smith-Lee Chong, P. 2004. Workplace bullying in a group context. British Journal of Guidance and Counselling 32, 301-317.

Cupach, W. R. \& Spitzberg, B. H. (toim.) 1994. The dark side of interpersonal communication. Hillsdale, NJ: Lawrence Erlbaum.

Cupach, W. R. \& Spitzberg, B. H. 2004. The dark side of relationship pursuit. From attraction to obsession and stalking. Mahwah, NJ: Lawrence Erlbaum.

Dindia, K. 2003. Definitions and perspectives on relational maintenance communication. Teoksessa D. J. Canary \& M. Dainton (toim.) Maintaining telationships through communication. Relational, contextual, and cultural variations. Mahwah, N.J.: Lawrence Erlbaum, 1-28.

Duck, S. 1994. Stratagems, spoils, and a serpent's tooth: On the delights and dilemmas of personal relationships. Teoksessa W. R. Cupach \& B. H. Spitzberg (toim.) The dark side of interpersonal communication. Hillsdale, NJ: Lawrence Erlbaum, 3-24.

Einarsen, S. 1996. Bullying and harassment at work: epidemiological and psychosocial aspects. University of Bergen, Norway. Department of Psychology. 
Einarsen, S. 1999. The nature and the causes of bullying at work. International Journal of Manpower 20, 16-27.

Einarsen, S. 2000. Harassment and bullying at work: a review of the Scandinavian approach. Aggression and Violent Behavior 5, 379-401.

Einarsen, S., Hoel, H., Zapf, D. \& Cooper, C. L. (toim.) 2003a. Bullying and emotional abuse in the workplace. International perspectives in research and practice. London: Taylor \& Francis.

Einarsen, S., Hoel, H., Zapf, D. \& Cooper, C. L. 2003b. The concept of bullying at work. The European tradition. Teoksessa S. Einarsen, H. Hoel, D. Zapf \& C. L. Cooper (toim.) Bullying and emotional abuse in the workplace. International perspectives in research and practice. London: Taylor \& Francis, 3-30.

Einarsen, S. \& Mikkelsen, E. G. 2003. Individual effects of exposure to bullying at work. Teoksessa S. Einarsen, H. Hoel, D. Zapf \& C. L. Cooper (toim.) Bullying and emotional abuse in the workplace. International perspectives in research and practice. London: Taylor \& Francis, 127-144.

Galvin, K. M. \&. Cooper, P. J. (toim.) 1996. Making connections: Readings in telational communication. Los Angeles, CA: Roxbury Publishing Company.

Hamarus, P. 2006. Koulukiusaaminen ilmiönä: yläkoulun oppilaiden kokemuksia kiusaamisesta. Jyväskylän yliopisto. Jyväskylä Studies in Education, Psychology and Social Research 288.

Harden Fritz, J. M. \& Omdahl, B. M. (toim.) 2006. Ptoblematic relationships in the workplace. New York: Peter Lang Publishing.

Hearn, J. \& Parkin, W. 2002. Gender, sexuality and violence in organizations. The unspoken forces of organizational violations. London: Sage.

Hess, J. A. 2000. Maintaining nonvoluntary relationships with disliked partners: An investigation into the use of distancing behaviors. Human Communication Research 26, 458-488.

Hess, J. A. 2003. Maintaining undesired relationships. Teoksessa D. J. Canary \& M. Dainton (toim.) Maintaining relationships through communication. Relational, contextual, and cultural variations. Mahwah, NJ: Lawrence Erlbaum, 103-124.

Hoel, H., Faragher, B. \& Cooper, C. L. 2004. Bullying is detrimental to health, but all bullying behaviours are not necessarily equally damaging. British Journal of Guidance and Counselling 32, 367-387.

Hogh, A. \& Dofradottir, A. 2001. Coping with bullying in the workplace. European Journal of Work and Organizational Psychology 10, 485-495.

Husso, M. 2003. Parisuhdeväkivalta. Lyötyjen aika ja tila. Tampere: Vastapaino.

Karhunen, S. 2004. Nuorten käsityksiä viestinnästä koulukiusaamistilanteissa. Jyväskylän yliopisto. Viestintätieteiden laitos. Puheviestinnän pro gradu 
-tutkielma.

Karhunen, S. 2006. Miksi meidän luokassa kiusataan? Arvioitavana oleva käsikirjoitus.

Kaukiainen, A. 2003. Social intelligence as a prerequisite of indirect aggression. Some manifestations and concomitants of covert forms of aggression. Turun yliopiston julkaisuja. Sarja B/257.

Keashly, L. \& Jagatic, K. 2003. By any other name: American perspectives on workplace bullying. Teoksessa S. Einarsen, H. Hoel, D. Zapf \& C. L. Cooper (toim.) Bullying and emotional abuse in the workplace. International perspectives in research and practice. London: Taylor \& Francis, 31-61.

Kelloway, K. E., Barling, J. \& Hurrell Jr, J. J. (toim.) 2006. Handbook of workplace violence. Thousand Oaks: Sage.

Kinney, T. A. 1998. The psychosomatic effects of negative interactions. Psychosomatic Medicine 60, 114.

Kinney, T. A. 2006. Should I stay or should I go? 'The role of negative communication and relational maintenance in distress and well-being. Teoksessa J. M.

Harden Fritz \& B. M. Omdahl (toim.) Problematic relationships in the workplace. New York: Peter Lang Publishing, 179-201.

Lahtinen, M., Vartia, M., Soini S. \& Joki, M. 2002. Työyhteisön ongelmatilanteet kehittämisen lähtökohtana. Teoksessa K. Lindström \& A. Leppänen (toim.) Työyhteisön terveys ja hyvinvointi. Helsinki: Työterveyslaitos, 94-102.

Lazarus, R. S. 1993. Coping theory and research: Past, present, and future. Psychosomatic Medicine 55, 234-247.

Ledley, D. R., Storch, E. A., Coles, M. E., Heimberg, R. G., Moser, J. \& Bravata, E. A. 2005. The relationship between childhood teasing and later interpersonal functioning. Journal of Psychopathology and Behavioral Assessment 28, 33-40.

Lewis, S. E. 2006. Recognition of workplace bullying: A qualitative study of women targets in public sector. Journal of Community and Applied Psychology 16, 119-135.

Leymann, H. 1996. The content and the development of mobbing at work. European Journal of Work and Organizational Psychology 5, 165-184.

Liefooghe, A. P. D. \& Olafsson, R. 1999. "Scientists" and "amateurs": mapping the bullying domain. International Journal of Manpower 20, 39- 49.

Lindström, K. \& Leppänen, A. (toim.) 2002. Työyhteisön terveys ja hyvinvointi. Helsinki: Työterveyslaitos.

Littlejohn, S. W. 1999. Theories of human communication. $6^{\text {th }}$ edition. Belmont: Wadsworth. 
Lutgen-Sandvik, P. 2006. Take this job and...: Quitting and other forms of resistance to workplace bullying. Communication Monographs 73, 406-433.

Ma, X. 2002. Builying in the middle school: individual and school characteristics of victims and offenders. School Effectiveness and School Improvement 13, 63-89.

Mannerheimin Lastensuojeluliitto. 2006. Kiusattu ei saa apua. Mannerheimin

Lastensuojeluliitos kiusaamiskysely. <http://www.mll.fi/ajankohtaista/uutiset/ ? $28190=139832>$. Viitattu 1.12.2006.

Michelson, G. \& Mouly, V. S. 2004. Do loose lips sink ships? The meaning, antecedents and consequences or rumour and gossip in organisations. Corporate Communications: An International Journal 9, 189-201.

Naylor, P. \& Cowie, H. 1999. The effectiveness of peer support system in challenging school bullying: the perspectives and experiences of teachers and pupils. Journal of Adolescence 22, 467-479.

Neuman, J. H. \& Baron, R. A. 2003. Social antecedents of bullying. A socialinteractionist perspective. Teoksessa S. Einarsen, H. Hoel, D. Zapf \& C. L. Cooper (toim.) Bullying and emotional abuse in the workplace. International perspectives in research and practice. London: Taylor \& Francis, 185-202.

Ólafsson, R. F. \& Jóhannsdóttir, H. L. 2004. Coping with bullying in the workplace: the effect of gender, age and type of bullying. British Journal of Guidance and Counselling 32, 319-333.

Olweus, D. 1992. Kiusaaminen koulussa. Suıom. M. Mäkelä. Helsinki: Otava.

Olweus, D. 2003. Bullying/victim problems in school: basic facts and an effective intervention programme. Teoksessa S. Einarsen, H. Hoel, D. Zapf \& C. L. Cooper (toim.) Bullying and emotional abuse in the workplace. International perspectives in research and practice. London: Taylor \& Francis, 62-78.

Payne, A. A. \& Gottfredson, D. C. 2004. Schools and bullying: school factors related to bullying and school-based bullying interventions. Teoksessa C.E. Sanders \& G.D. Phye (toim.) Bullying. Implications for the classroom. Amsterdam: Elsevier Academic Press, 159-176.

Pepler, D. \& Craig, W. 2000. Making difference in bullying. LaMarsh Report 59. Toronto: York University.

Pikas, A. 1990. Irti kouluväkivallasta. Suomentaja E. Pilvinen. Espoo: Weilin+Göös.

Pörhölä, M. 2006. Relational implications of school bullying: Developmental pathways in victims' interpersonal relationships. Paper presented at the International Association for Relationship Research Conference, July 6-10, Rethymnon, Crete.

Pörhölä, M., Karhunen, S., \& Rainivaara, S. 2006. Bullying at school and in the 
workplace. A challenge for communication research. Teoksessa C. Beck (toim.) Communication Yearbook 30. Mahwah, NJ: Lawrence Erlbaum, 249-301.

Rainivaara, S. 2004. "Sinä olet varmasti hyvä jossakin". Kiusatun näkemyksiä viestinnästä ja työyhteisön tuesta työpaikkakiusaamistilanteissa. Jyräskylän yliopisto. Viestintätieteiden laitos. Puheviestinnän pro gradu -tutkielma.

Randall, P. 2001. Bullying in adulthood. Assessing the bullies and their victims. East Sussex, GB: Brtunner-Routledge.

Rayner, C. \& Cooper, C. L. 2006. Workplace bullying. Teoksessa K. E. Kelloway, J. Barling \& J. J. Hurrell Jr (toim.) Handbook of workplace violence. Thousand Oaks: Sage, 121-145.

Reinboth, C. 2006. Tunnista ja torju työpaikkakiusaaminen. Helsinki: Yrityskirjat .

Richards, J. \& Daley, H. 2003. Bullying policy: Development, implementation and monitoring. Teoksessa S. Einarsen, H. Hoel, D. Zapf \& C. L. Cooper (toim.) Bullying and emotional abuse in the workplace. International perspectives in research and practice. London: Taylor \& Francis, 127-144.

Rigby, K. 2004. Addressing bullying in schools. Theoretical perspectives and their implications. School Psychology International 25, 287-300.

Salmivalli, C. 1998. Koulukiusaaminen ryhmäilmiönä. Tampere: Gaudeamus.

Salmivalli, C. 1999. Participant role approach to school bullying: implication for interventions. Journal of Adolescence 22, 453-459.

Salmivalli, C. 2003. Koulukiusaamiseen puuttuminen. Jyväskylä: PS-kustannus.

Salmivalli, C. 2005. Kaverien kanssa. Vertaissuhteet ja sosiaalinen kehitys. Jyväskylä: PS-kustannus.

Salmivalli, C., Karhunen J. \& Lagerspetz, K. M. J. 1996. How do the victims respond to bullying? Aggressive Behavior 22, 99-109.

Salmivalli, C. \& Voeten, M. 2004. Connections between attitudes, group norms, and behaviors associated with bullying in schools. International Journal of Behavioral Development 28, 246-258.

Sanders, C.E. \& Phye, G.D. (toim.) 2004. Bullying. Implications for the classroom. Ansterdam: Elsevier Academic Press.

Smith, P. K., Singer, M., Hoel, H. \& Cooper, C.L. 2003. Victimization in the school and the workplace: are there any links? The British Psychological Society 94, 175-188.

Sunwolf \& Leets, L. 2003. Communication paralysis during peer-group exclusion.

Social dynamics that prevent children and adolescents from expressing disagreement. Journal of Language and Social Psychology 22, 1-30. 
Teräsahjo, T. \& Salmivalli, C. 2002. "Se tavallaan haluu olla yksin."

Koulukiusaamisen tulkintarepertuaarit ala-asteen oppilaiden puheissa. Psykologia 37, 101-114.

Thylefors, I. 1987. Syndabockar. Om utstötning och mobbning I arbetslivet. Stockholm: Natur och kultur.

Työturvallisuuslaki 23.8.2002/738, 28 \&

Vardi, Y. \& Weitz, E. 2004. Misbehavior in organizations. Theory, research, and management. Mahwah, NJ: Lawrence Erlbaum.

Vartia, M. 2003. Workplace bullying - A study on the work environment, well being and health. People and Work Research Reports 56. Helsinki: Työterveyslaitos.

Vartia, M., Korppoo, L., Fallenius, S. \& Mattila, M.-L. 2003. Workplace bullying. The role of occupational health services. Teoksessa S. Einarsen, H. Hoel, D. Zapf \& C. L. Cooper (toim.) Bullying and emotional abuse in the workplace. International perspectives in research and practise. London: Taylor \& Francis, $285-298$

Wilmot, W. 1996. 'The relational perspective. Teoksessa K. M. Galvin \& P. J. Cooper (toim.) Making connections: Readings in relational communication. Los Angeles, CA: Roxbury Publishing Company, 16-24.

Whitney, I. \& Smith, P. K. 1993. A survey of the nature and extent of bullying in junior/middle school and secondary schools. Educational Reseatch 35, 3-26.

Wood, j. 1996. Communication and relational culture. Teoksessa K. M. Galvin \& P. J. Cooper: (toim.) Making connections: Readings in Relational Communication. Los Angeles, CA: Roxbury Publishing Company, 11-15.

Zapf, D. 1999. Organisational, work group related and personal causes of mobbing/bullying at work. International Journal of Manpower 20, 70-85.

Zapf, D. \& Einarsen, S. 2003. Individual antecedents of bullying: victims and perpetrators. Teoksessa S. Einarsen, H. Hoel, D. Zapf \& C. L. Cooper (toim.) Bullying and emotional abuse in the workplace. International perspectives in research and practice. London: Taylor \& Francis, 165-184.

Zapf, D. \& Gross, C. 2001. Conflict escalation and coping with workplace bullying: A replication and extension. European Journal of Work and Organizational Psychology 10, 497-522. 